\title{
Development of a model of Ascaris Suum antigen-induced pulmonary inflammation in nonhuman primates
}

\author{
Andrea G Bree, Franklin J Schlerman, Michael D Wadanoli, I-Ming Wang, Samuel J Goldman, Joseph P Sypek
}

From 2nd Cross Company Respiratory Symposium

Horsham, UK. 6-7 September 2012

\begin{abstract}
Airway inflammation is one of the hallmarks of asthma and can contribute to airway hyperresponsiveness. Using cynomolgus monkeys (Macaca fascicularis) that are naturally sensitized to Ascaris suum antigen in the wild, we developed a reproducible model of acute airway inflammation following segmental A.suum antigen challenge. A pediatric bronchoscope was used to perform bronchoalveolar lavage (BAL) for the collection of BAL cells and fluid (BALF). The bronchoscope was also used for the administration of a segmental lung A.suum challenge. Baseline BAL was performed on one lung prior to segmental antigen challenge on the opposite lung. BAL on the challenged lung was performed 24 hours postchallenge to assess pulmonary inflammation. As compared to baseline lavage, a single airway challenge with A.suum antigen, at a dose of 0.50 or $0.75 \mathrm{mg} /$ challenge, resulted in a reproducible pulmonary inflammation. The inflammation was characterized by an increase in total BAL cell counts and increased eosinophils. From concentrated BALF samples, taken 24 hours post A.suum antigen challenge, there was also a trend towards increased IL-5 and eotaxin as measured by ELISA. In some studies, animals were treated with two doses of the steroid, dexamethasone (DEX), $1 \mathrm{mg} / \mathrm{kg}$ by IM injection, prior to antigen challenge. In these studies, administration of DEX prior to antigen challenge prevented airway inflammation. These data show that segmental challenge with A. suum antigen produced an acute pulmonary eosinophilic inflammation that was prevented by pretreatment with the steroid, dexamethasone. This model should be useful for testing the efficacy of selected drug candidates, as compared to proven anti-inflammatory therapy, in blocking
\end{abstract}

Inflammation and Remodeling Research, Pfizer Cambridge Massachusetts, 02140, USA

() Biomed Central

(c) 2013 Bree et al; licensee BioMed Central Ltd. This is an Open Access article distributed under the terms of the Creative Commons Attribution License (http://creativecommons.org/licenses/by/2.0), which permits unrestricted use, distribution, and reproduction in any medium, provided the original work is properly cited. the pulmonary inflammatory response to A. suum in a large animal model.

Published: 14 August 2013

doi:10.1186/1476-9255-10-S1-P16

Cite this article as: Bree et al:: Development of a model of Ascaris Suum antigen-induced pulmonary inflammation in nonhuman primates.

Journal of Inflammation 2013 10(Suppl 1):P16.

Submit your next manuscript to BioMed Central and take full advantage of:

- Convenient online submission

- Thorough peer review

- No space constraints or color figure charges

- Inclusion in PubMed, CAS, Scopus and Google Scholar

- Research which is freely available for redistribution Submit your manuscript at
www.biomedcentral.com/submit C Biomed Central
- Immediate publication on acceptance 